\title{
KRITIK TERHADAP PEMIKIRAN JALALUDIN RAKHMAT DALAM BUKU $A L$ - MUSHTHAFA TENTANG HADIS MUDHTHARIB PADA SHAHÎH AL-BUKHÂR̂ि: STUDI ANALISIS HADIS ABU BAKAR MENJADI IMAM SALAT
}

\author{
Kinkin Syamsudin \\ Program Pascasarjana UIN Gunung Djati Bandung \\ E-Mail: Kinkin@Gmail.Com
}

\begin{abstract}
Jalaluddin Rachmat is one of the Indonesian Muslim leaders who had concerns over issues of religion, including Islam. Through his writings, he devoted some of his ideas about perspective in understanding Islam and the problems that exist in it. In the book Al-Mustafa Jalal assume that the traditions that tells the events of Abu Bakr became imam prayer in the last days before the Prophet died Hadith mudhtharib. He presents at least six reasons why the hadith narrated by Al-Bukhari it deserves to be discredited because it can not be used as evidence. This paper attempts to explore what kind of methodology used in the Jalal interpret the hadiths in question. The research focused on two issues, namely 1) the concept of tradition mudhtharib by Jalaluddin Rachmat, 2) the argument about the existence of Jalaluddin Rachmat mudhtharib hadith in Sahih al-Bukhari.
\end{abstract}

Keywords: mudhtharib, Saheeh al-Bukari, Abu Bakr.

\begin{abstract}
Abstrak
Jalaludin Rakhmat adalah salah satu tokoh muslim Indonesia yang memiliki konsern terhadap isu-isu agama, termasuk Islam. Melalui berbagai tulisannya, ia mencurahkan beberapa gagasannya tentang cara pandang dalam memahami Islam dan berbagai permasalahan yang ada di dalamnya. Dalam buku Al-Mushthafa, Jalal berasumsi bahwa hadis-hadis yang menceritakan peristiwa Abu Bakar menjadi imam salat di hari-hari terakhir sebelum Rasulullah wafat adalah hadis mudhtharib. Ia menyuguhkan setidaknya ada enam alasan kenapa hadis yang diriwayatkan oleh Al-Bukhari itu patut untuk diragukan keabsahannya karena tidak bisa dijadikan hujjah. Tulisan ini mencoba untuk menggali seperti apa metodologi yang digunakan Jalal dalam memaknai hadis-hadis yang dimaksud. Adapun penelitiannya difokuskan pada dua permasalahan, yaitu 1) konsep hadis mudhtharib menurut Jalaludin Rakhmat, 2) argumentasi Jalaludin Rakhmat tentang adanya hadis mudhtharib dalam Shahîh al-Bukhârî.
\end{abstract}

Kata Kunci: mudhtharib, shahih al-Bukari, Abu Bakar.

\section{A. PENDAHULUAN}

Di antara kitab hadis yang menghimpun tentang hadis-hadis shahih adalah kitab yang disusun oleh Muhammad bin Ismail alBukhari yaitu Shahîh al-Bukhârî. Dalam kitab ini berisi tentang ribuan hadis yang derajat sanadnya merupakan sanad yang paling tinggi dan oleh mayoritas ulama kitab hadis ini dianggap sebagai kitab paling shahih kedua setelah al-Quran. ${ }^{1}$

${ }^{1}$ Taqiyuddîn Abû al-'Abbâs Ahmad bin 'Abdulhalîm bin Taimiyyah Al-Haran, Majmû' AlFatawâ, ed. by 'Abdurrahmân bin Muhammad bin Qâsim (Madinah: Majma' al-Malik Fahd li Thaba'ah al-Mushahaf asy-Syarîf, 1995), XX, p. 321.; Ahmad Muhammad Syâkir, Al-Bâ'its Al-Hatsîts; Syarh Ikhtishâr 'Ulûm Al-Hadîs Li Al-Hâfizh Ibnu Katsîr (Riyadh: Maktabah Dâr as-Salâm, 1994), p. 3.; Badruddin Al-'Aini, Umdah Al-Qari Syarh Shahih AlBukhar (Beirut: Dar Kutub al-'Ilmiyyah, 2001), XII, p. 5.; Syamsuddîn Abû al-Khair Muhammad bin
Meskipun demikian, kitab Shahîh $\underline{h}$ alBukhârî bukan berarti tidak lepas dari kritik dan hujatan para ulama, baik ulama hadis salaf maupun ulama hadis khalaf. Di antara kritikan dari ulama hadis salaf adalah tentang pencantuman hadis mu'allaq yang ada dalam kitab tersebut. Dan secara gamblang kritikan tersebut sudah dibantah secara tuntas oleh Ibn Hajar al-'Asqalani (w. $852 \mathrm{H}$ ) dalam kitabnya yang diberi judul Taghlîq at-Ta'lîq 'alâ Shahîh $\underline{h}$ al-Bukhârî. Selain itu, kritikan juga datang dari Imam ad-Daruquthni (w. $385 \mathrm{H}$ ) dalam kitab Al-Ilzamat wa atTatabbu'. Dalam kitab tersebut beliau

\footnotetext{
'Abdurrahmân As-Sakhâwî, Fath Al-Mughîts Bisyarh Alfiyyah Al-Hadîs, ed. by 'Abdulkarîm bin 'Abdirrahmân Al-Khudhair (Riyadh: Maktabah Dâr al-Minhâj, 2005), I, p. 53.; abd al-Rahman bin abi bakar jalaludin Al-suyuti, Tadrib Al Rawiy Fi Syarhi Taqrib Al Nawawi (maktabah syamilah), p. 92.
} 
memuat 210 hadis riwayat Bukhari yang dianggap sebagai hadis mu'allal.

Sementara kritikan di zaman sekarang di antaranya datang dari Jalaludin Rakhmat. Ia sebenarnya bukan seorang ahli hadis, dalam dunia akademik ia lebih dikenal sebagai pakar komunikasi. Namun dalam beberapa buku yang ia tulis, ia sering menyinggung tentang hadis dan berbagai problematika yang terkait dengannya. Ia berasumsi bahwa keberadaan hadis yang selama ini sangat dimuliakan oleh umat Islam dan dijadikan sebagai sumber hukum kedua setelah alQuran, bukan berarti tanpa problem di dalamnya. Hadis-hadis yang sampai kepada kita sekarang harus diteliti ulang dan dicek kembali keabsahannya sebagaimana hal ini juga pernah dilakukan oleh para ulama hadis terdahulu.

Dalam buku Al-Mushthafa, ${ }^{2}$ yaitu buku yang ia tulis dan dimaksudkan sebagai buku pengantar studi kritis terhadap tarikh Nabi, Jalaludin Rakhmat melakukan dekontruksi pemahaman terhadap beberapa hadis yang ia anggap bermasalah, meskipun hadis-hadis tersebut sudah disepakati oleh para ulama hadis sebagai hadis yang berderajat shahih. Dalam salah satu tesisnya ia mengatakan, "Jika para ahli hadis begitu teliti dan begitu keras dalam menetapkan kriteria penetapan hadis, mengapa kita tidak kritis pada riwayatriwayat Nabi SAW yang sampai kepada kita, terutama dalam kitab-kitab tarikh". 3

Kritik hadis yang dilakukan oleh Jalaludin Rakhmat dalam hal ini di antaranya juga langsung ditujukan kepada kitab Shahih alBukhari. Dalam buku Al-Mushthafa, ia mengatakan bahwa hadis-hadis riwayat Bukhari yang berbicara tentang Abu Bakar yang menjadi imam salat pada hari-hari

\footnotetext{
2 Buku ini sudah diterbitkan sebanyak dua kali. Edisi pertama diterbitkan oleh Muthahhari Press, dicetak pada Juni 2002 di Bandung dengan spesifikasi sebanyak xv halaman pengantar dan 183 halaman isi, dan judul lengkapnya adalah Al-Mustafa; Pengantar Studi Kritis Tarikh Nabi Sementara edisi kedua diterbitkan oleh Simbiosa Rekatama Media Bandung, dicetak pada April 2008, terdiri dari xvii halaman pengantar dan 210 halaman isi dengan judul $\mathrm{Al}$ Mushthafa; Manusia Pilihan Yang Disucikan.

3 Jalaludin Rakhmat, Al-Mushthafa (Bandung: Muthahhari Press, 2002), p. x..
}

terakhir Rasulullah adalah hadis-hadis yang bermasalah matannya.

Dalam buku Al-Mushthafa, Jalaludin Rakhmat mengatakan bahwa hadis-hadis yang menceritakan Abu Bakar menjadi imam salat redaksinya tidak konsisten dan oleh karenanya dalam ilmu hadis riwayat seperti itu disebut sebagai hadis mudhtharib dan tergolong sebagai salah satu macam hadis dha 'if. ${ }^{4}$ Disebut mudhtharib karena redaksi matan hadis-hadis tersebut tidak sama dan bahkan saling bertentangan; satu hadis mengatakan bahwa Rasulullah salat di sebelah kiri Abu Bakar dan hadis lain mengatakan bahwa Rasulullah salat di hadapan Abu Bakar. Di sisi lain, dikatakan bahwa yang menjadi imam adalah Abu Bakar, sementara pada hadis yang lainnya lagi disebutkan bahwa Rasulullahlah yang menjadi imam.

\section{B. PEMBAHASAN}

\section{Hadis Mudhtharib dalam Shahih al- Bukhari}

Bukan tanpa alasan jika Jalal mengatakan bahwa hadis-hadis riwayat Bukhari yang menceritakan Abu Bakar menjadi imam salat terindikasi sebagai hadis mudhtharib. Ada beberapa alasan yang menurut asumsinya kenapa hadis tersebut dihukumi sebagai hadis mudhtharib. Di antara indikasi-indikasinya bisa terlihat dalam beberapa kontradiksi berikut: $^{5}$

Pertama, kontradiksi perilaku Rasulullah dalam salatnya. Dalam hadis Bukhari nomor 713 Rasulullah dikatakan jalasa 'an yasâri Ab̂̀ Bakrin (duduk di sebelah kiri Abu Bakar). Dalam hadis nomor 683 Rasulullah fa jalasa hidzầa Abî Bakrin (duduk di hadapan Abu Bakar). Sementara dalam hadis nomor 664 Rasulullah duduk di sebelah kanan Abu Bakar, masih dalam Shahîh $\underline{h}$ alBukhârî dan hanya diantarai oleh beberapa halaman saja. Ini kontradiksi, satu redaksi mengatakan hidzâ‘a (di hadapan), satu mengatakan 'an yasâri (di sebelah kiri) dan riwayat satu lagi mengatakan 'an yamîni (di sebelah kanan). Boleh saja kita

\footnotetext{
${ }^{4}$ Rakhmat, p. 111.

${ }^{5}$ Rakhmat, pp. 91-93.
} 
menggabungkan ketiga-tiganya, jadi Rasulullah berhadap-hadapan, kemudian pindah ke sebelah kiri dan pindah ke sebelah kanan.

Kedua, kontradiksi antara Abu Bakar (yang menjadi makmum dan berdiri) dengan Rasulullah (yang menjadi imam dan duduk). Lihat hadis riwayat Bukhari nomor 722 . Ketiga, kontradiksi dalam menafsirkan peristiwa itu. Apakah imamnya satu yaitu Abu Bakar, atau dua yaitu Abu Bakar dan Rasulullah? Berdasarkan satu riwayat, Rasulullah tidak ikut salat. Beliau hanya membuka tirai saja, karena beliau sakit parah. Lalu Abu Bakar mundur karena melihat Rasulullah datang. Kata Rasulullah, 'Teruskan saja!' Rasulullah tidak salat, dan Abu Bakar menjadi imam. Dalam riwayat yang lain tidak, Abu Bakar mundur, kemudian Rasulullah maju dan menjadi imam. Rasulullah duduk sebagai imam dan Abu Bakar berdiri sebagai makmumnya. Orang banyak bermakmum kepada Abu Bakar. Atau imamnya ada dua, yaitu Abu Bakar dan Rasulullah.

Kalau berdasarkan fikih, tidak boleh imam itu lebih dari satu orang. Makmum sih boleh lebih dari satu orang. Lucunya, dalam hadis Shahîh al-Bukhârî nomor 722 itu disebutkan bahwa kalau imam itu duduk, makmum pun harus duduk pula. Jadi, bagaimana hadis itu? Rasulullah jadi imam dan duduk sedangkan Abu Bakar berdiri. Sukar mendamaikan kedua hadis itu.

Keempat, dalam hadis Bukhari nomor 3667 disebutkan oleh Siti Aisyah bahwa Rasulullah wafat, sementara Abu Bakar berada di Sunh, sebuah tempat kira-kira beberapa puluh kilometer di luar kota Madinah. Jadi, pada hari-hari terakhir Rasulullah Abu Bakar tidak berada di Madinah. Karena itu peristiwa Abu Bakar menjadi imam salat agak diragukan terjadinya. Abu Bakar tidak berada di Madinah pada hari-hari terakhir Rasulullah. Ini menurut Siti Aisyah yang justru menceritakan peristiwa salat itu. Jadi orang yang sama bercerita pada satu riwayat Abu Bakar tidak berada di Madinah dan pada riwayat yang lain ia berada di Madinah.
Kelima, dalam hampir seluruh kitab tarikh disebutkan bahwa Abu Bakar pada hari-hari terakhir Rasulullah berada dalam pasukan Usamah pada suatu tempat yang bernama Jurf. Malah diriwayatkan begitu sampai di Jurf, Abu Bakar mendengar bahwa Rasulullah meninggal dunia. Segera ia bergegas kembali dari Jurf. Ada juga riwayat bahwa 'Umar lebih dahulu tahu tentang meninggalnya Rasulullah dan ia tidak memercayainya. Ia baru yakin Rasulullah meninggal dunia setelah Abu Bakar datang dari luar kota. Padahal dalam hadis yang kita bicarakan disebutkan bahwa perintah menyuruh salat itu terjadi pada hari terakhir, karena keesokan harinya Rasulullah meninggal dunia. Dan pada waktu itu, Abu Bakar masih berada di Jurf.

Keenam, pada satu riwayat Rasulullah menyuruh Abu Bakar menjadi imam salat berjama'ah (lihat hadis Bukhari nomor 680 dan 681) sedangkan pada riwayat yang lain Rasulullah menjadi imam (lihat kontradiksi nomor 2).

Dalam statemen terakhirnya Jalal mengatakan, "Jadi kalau kita menemukan hadis-hadis yang seperti itu, maka dengan terpaksa kita harus meragukan kebenaran peristiwa itu terjadi. Dalam peribahasa Belanda dikatakan bahwa kebohongan tidak punya kaki, ia goyah. Berbohong itu sukar dan kebohongan itu biasanya hanya bisa dipertahankan melalui kebohongan lagi. Karena itu, dalam berita bohong dengan mudah kita temukan inkonsistensi". 6

\section{Kritik Terhadap Istilah Mudhtharib ala Jalaludin Rakhmat}

Ijtihad Jalal dalam menentukan hadishadis Shahîh $\underline{h}$ al-Bukhârî yang ia anggap mudhtharib adalah dengan cara melihat beberapa kontradiksi yang timbul dari hadis yang dimaksud. Pertama, ia melihat hadis tersebut dari sisi lafziyyah matan hadis, lalu mengkomparasikannya dengan hadis lain yang berbeda sanadnya, tetapi memiliki redaksi yang hampir sama. Kemudian dari dua riwayat itu dicari kalimat tertentu yang kira-kira bisa menjadikan kedua hadis

\footnotetext{
${ }^{6}$ Rakhmat, p. 94
} 
tersebut saling bertolak belakang maknanya. Dalam hal ini, ketika Jalal mengutip hadis Bukhari nomor 713 yang di dalamnya redaksi yang dikatakan bahwa Rasulullah itu duduk di samping kiri Abu Bakar ( جَلَنَ عَنْ يَسَارِ iأَبِي بَخْرِ hadis Bukhari nomor 683 yang dalam redaksinya dikatakan bahwa Rasulullah itu duduk di depan Abu Bakar (فَجَلَسَ رَسُوْلُ اللهِ ص حِذَاء (أبَي بَكْرِ 664 juga hadis nomor mengatakan bahwa Nabi duduk di samping kanan Abu Bakar (jalasa 'an yamini Abi Bakrin).

Al-Waluwwi menjelaskan bahwa perbedan lafazh atau matan hadis itu tidak selamanya menjadikan hadis tersebut duhukumi sebagai mudhtharib. Ia mengatakan, "Apabila memungkinkan untuk digabung, dimana pembicara itu mengatakan dua lafazh atau lebih tetapi memiliki satu makna atau tiap-tiap darinya menjelaskan satu kondisi dan tidak bertentangan dengan yang lain, maka tidak dianggap mudhtharib". 7

Kedua, Jalal mengkomparasikan hadishadis yang semakna dengan hadis lain yang berbeda maknanya tetapi memiliki kemiripan isinya. Berkaitan dengan hal ini ia mengatakan bahwa riwayat yang menyebutkan Rasulullah yang saat itu menjadi imam salat sambil duduksementara Abu Bakar dan para sahabat lainnya berdiri-bertentangan dengan perkataan beliau sendiri yang mengatakan bahwa makmum harus senantiasa mengikuti imam. Sementara peristiwa yang terjadi dalam hal ini tidak seperti yang diintruksikan oleh Rasulullah. Beliau tidak menyuruh Abu Bakar dan para sahabat lainnya untuk salat sambil duduk, begitu juga Abu Bakar dan para sahabat tidak langsung duduk sebagaimana yang dilakukan oleh Rasulullah.

Jalal menganggap bahwa apa yang dilakukan oleh Rasulullah bertentangan dengan apa yang beliau katakan sendiri. Jika demikian, maka hadis yang memerintahkan

${ }^{7}$ Muhammad bin al-'Allamah Al-Waluwwi, Syarh Alfiyah as-Suyûthî Fî̀ Al-Hadîs (Madinah: Maktabah al-Ghurabâ al-Atsariyyah, 1993), I, p. 265. makmum untuk mengikuti imam itu bisa ditolak, karena dalam kenyataannya Rasulullah pun tidak memerintahkan hal tersebut kepada para sahabat. Atau bisa juga dipahami bahwa apa yang dilakukan oleh Rasulullah dan para sahabat itu adalah pelanggaran terhadap apa yang sudah beliau sabdakan.

Untuk memahami apakah hadis-hadis di atas tergolong sebagai hadis mudhtharib atau tidak, ada baiknya jika kita perhatikan perkataan Ibnu Shalah berikut ini, "Kami menyebut mudhtharib itu jika ada dua riwayat yang sama, adapun jika salah satu riwayat lebih kuat dimana yang lainnya tidak lebih kuat dari riwayat tersebut karena rawinya lebih hafizh atau banyaknya orang yang meriwayatkan darinya atau selain hal itu berupa faktor-faktor penguat lain yang beragam, maka (hadis itu) dihukumi rajih (kuat). Dengan demikian, sifat mudhtharib itu tidak berlaku bagi hadis yang rajih karena untuk hadis seperti itu tidak ada hukum mudhtharib baginya". ${ }^{8}$

Jika berpegang pada perkataan Ibnu Shalah di atas, maka suatu hadis disebut mudhtharib itu ialah jika kedua riwayatnya memiliki derajat yang sama dan tidak memungkinkan untuk mentarjih (memilih yang lebih kuat) salah satunya. Hal yang sama juga diungkapkan oleh Zakaria bin Ahmad al-Anshari bahwa disebut mudhtharib itu ialah apabila ada dua riwayat berbeda yang sama dalam keshahîhannya dan salah satu riwayatnya tidak lebih kuat dari yang lain". 9

Ketiga, Jalal membandingkan hadis yang dimaksud dengan hadis atau peristiwa lain di luar dari redaksi/matan hadis yang bersangkutan. Berkaitan dengan riwayat Abu Bakar menjadi imam, Jalal mengatakan bahwa peristiwa tersebut bertentangan dengan hadis Bukhari nomor 3667 yang mengatakan bahwa pada saat-saat sebelum

${ }^{8} \mathrm{Abu}$ 'Amr 'Abdurrahman Asy-Syahrazuri, Muqaddimah Ibnu Shalah Fî 'Ulum Al-Hadis (kairo: Dar al-Hadis, 2010), p. 124.

9 Zainuddin bin Ahmad al-Anshari Al-Azhari, Syarh Alfiyah Al-'Iraqi, ed. by Muhammad al-'Iraqi Al-Husaini (Beirut: Dar al-Kutub al-'Ilmiyyah), p. 240. 
Rasulullah wafat ia sedang berada di Sunh. Kedua peristiwa tersebut sulit untuk dipahami, padahal keduanya berasal dari satu sumber yang sama, yaitu Aisyah. Selain itu, peristiwa ini juga bertentangan dengan riwayat yang dikisahkan dalam beberapa kitab tarikh yang menyebutkan bahwa pada hari-hari terakhir sebelum Rasulullah wafat, Abu Bakar sedang berada dalam pasukan Usamah di Jurf.

Jika asumsi Jalal ini benar maka sejatinya hadis mudhtharib itu harus ditolak, sebagaimana yang sudah disepakti oleh para ulama bahwa hadis semacam itu tidak dianggap dhabth karena ada kerancuan dalam riwayatnya sehingga tidak memungkinkan untuk bisa ditakwilkan dan dipahami maknanya. Semua ulama hadis sepakat bahwa hadis mudhtharib adalah bagian dari hadis dha'if.

Ikhtiar Jalal dalam melakukan kritik matan hadis memang sah-sah saja, karena hal itu sudah dipraktikkan oleh para ulama hadis terdahulu. Sayangnya, studi kritis yang ia lakukan hanya didasarkan pada asumsi sederhana yang ia buat sendiri. Dalam kaitannya dengan hadis mudhtharib, ia tidak memberikan batasan yang jelas tentang mudhtharib seperti apa dan konsep siapa yang sebenarnya ia pakai. Jalal tidak memberikan pemahaman yang komprehensif tentang hadis mudhtharib. Argumentasi mudhtharib yang ia kemukakan sama sekali tidak didasarkan kepada teori yang telah dirumuskan dan disepakati oleh para ulama hadis. Kalaupun ia tetap mempertahankannya, maka patut dipertanyakan definisi mudhtharib seperti apa yang sebenarnya ia maksud.

Dengan demikian, asumsi Jalal yang mengatakan bahwa terdapat hadis mudhtharib dalam Shahih al-Bukhari itu tidak bisa diterima. Selain karena hadis-hadis dalam Shahih al-Bukhari itu sudah disepakati keshahihannya, ${ }^{10}$ istilah mudhtharib yang

${ }^{10}$ Muhammad bin 'Ali bin Muhammad bin 'Abdillah Asy-Syaukani, Irsyad Al-Fuhul Ila Tahqiq Al-Haqq Min 'Ilm Al-Ushul, ed. by Asy-Syaikh Ahmad 'Auz 'Inayah (Beirut: Dâr al-Kutub al-'Arâbî, 1999), I, p. 138., lihat juga dalam kitab Muhammad bin 'Ali bin Muhammad bin 'Abdillah Asy-Syaukani, disebutkan oleh Jalal juga tidak jelas dan berseberangan dengan konsep yang sudah disepakati oleh mayoritas ulama hadis. ${ }^{11}$

\section{Kritik Terhadap Argumentasi Jalal Argumen pertama}

Dalam hadis Bukhari nomor 713 Rasulullah dikatakan jalasa 'an yasâri Abî Bakrin (duduk di sebelah kiri Abu Bakar). Dalam hadis Bukhari nomor 683 fajalasa Rasulullah hizda`a Abî Bakrin (Rasulullah duduk di hadapan Abu Bakar). Sementara dalam hadis Bukhari nomor 664 Rasulullah duduk di sebelah kanan Abu Bakar, jalasa 'an yamîni Ab̂̂ Bakrin. Hadis-hadis tersebut masih dalam Shahih Bukhari dan hanya diantarai oleh beberapa halaman saja. Ini kontradiksi, satu redaksi mengatakan hidzâ'a (di hadapan), satu mengatakan 'an yasâri (di sebelah kiri) dan riwayat satu lagi mengatakan 'an yamîni (di sebelah kanan). Boleh saja kita menggabungkan ketigatiganya, jadi Rasulullah berhadap-hadapan, kemudian pindah ke sebelah kiri dan pindah ke sebelah kanan. ${ }^{12}$

Ketiga hadis di atas datang dari satu sumber yang sama yaitu Aisyah, dan menceritakan satu peristiwa yang sama pula. Meskipun sama, tapi menurut Jalal dalam

Qathr Al-Wali 'ala Hadis Al-Wali (kairo: Dâr alKutub al-Hadîtsah), p. 218.; Asy-Syahrazuri, p. 48.;Shalâhuddîn Abû Sa'̂̂d Khalîl bin Kîkaldî al'Alâ'î, Tahqîq Al-Murâd Fî Anna an-Nahy Yaqtadhî Al-Fasâd (Kuwait: Dâr al-Kutub ats-Tsaafiyyah), p. 114.

${ }^{11}$ Para ulama hadis semisal Ibnu Shalâh, al-'Irâqî, as-Sakhâwî, Ahmad Syâkir, al-Albânî, al-Waluwwî dan 'Abdurrahmân al-Khumaisî semuanya memberikan gambaran dan batasan yang jelas bahwa hadis mudhtharib adalah hadis yang diriwayatkan dari jalur yang berbeda-beda serta sama dalam tingkat kekuatannya, dimana satu jalur dengan yang lainnya tidak memungkinkan untuk disatukan atau digabungkan, dan tidak memungkinkan pula untuk dipilih salah satu yang terkuat. Akan tetapi jika antara jalur satu dengan yang lainnya dapat disatukan atau digabungkan, maka hilanglah ketidakjelasannya (idhthirâb) itu dan dibolehkan untuk mengamalkan semua riwayat. Jika dapat dipilih salah satu yang terkuat, maka yang boleh untuk diamalkan adalah riwayat yang terkuat saja. Lihat Asy-Syahrazuri, p. 124.; (Syâkir, 1994, p. 78); (Syâkir, 1994, p. 78), Syâkir, p. 78.; (Rakhmat, 2002, p. 91).

${ }^{12}$ Rakhmat, p. 91. 
ketiga hadis tersebut ada perbedaan, di dalam hadis-hadis itu diceritakan tentang posisi salat Rasulullah yang berbeda-beda. Dalam hadis yang pertama (hadis Bukhari nomor 713) dikatakan bahwa Rasulullah datang, lalu duduk di samping kiri Abu Bakar;

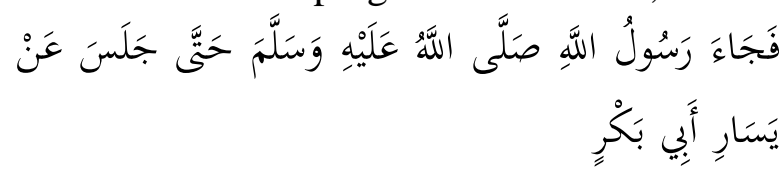

Sementara dalam hadis yang kedua (hadis Bukhari nomor 683) dikatakan bahwa Rasulullah duduk di hadapan Abu Bakar;

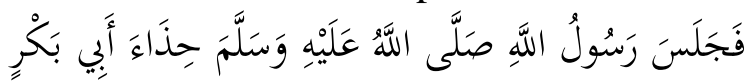

Dalam dalam hadis yang ketiga (hadis Bukhari nomor 664) dikatakan bahwa Rasulullah duduk di sebelah kanan.

Bila dicermati maka akan tampak beberapa syubhat asumsi Jalal; pertama, ketiga hadis riwayat Bukhari tersebut disimpan oleh Imam Bukhari dalam bab yang berbeda, meskipun ketiganya sama-sama ditempatkan dalam kitab adzan. Hadis nomor 713 disimpan pada kitab adzan, bab seseorang mengikuti imam dan orang lain mengikuti gerakan makmum yang ada di depannya, sedangkan hadis nomor 683 disimpan pada kitab adzan, bab orang yang berdiri di sisi imam karena alasan tertentu dan hadis nomor 664 disimpan pada kitab adzan, bab batasan orang sakit boleh menghadiri salat berjama'ah. Hal ini memberi indikasi dan faedah bahwa dari ketiga hadis tersebut bisa diambil tiga kesimpulan (isthinbath) yang berbeda. Artinya, ketiga hadis tersebut bisa dipahami dan ditempatkan berdasarkan kepentingan istinbathnya. Hadis pertama memberi faedah bahwa makmum yang banyak boleh mengikuti gerakan seorang makmum yang langsung bermakmun kepada imam, kedua dalam kondisi tertentu makmum boleh berdiri langsung dekat imam dan ketiga batasan bagi orang sakit untuk menghadiri salat berjama'ah.

Kedua, Jalal keliru dalam mencantumkan hadis Bukhari nomor 664 sebagai bagian dari hadis yang kontradiksi dalam memahami hadis Bukhari nomor 713. Ia mengatakan bahwa dalam hadis Bukhari nomor 664
Rasulullah duduk di sebelah kanan (عَنْ يَيِْن) Abu Bakar. Padahal dalam hadis tersebut tidak ada kalimat seperti itu, redaksi yang ada dalam hadis adalah "sehingga beliau (Rasulullah) duduk di sampingnya", حَتَّى جَلَسَ dan kalimat "beliau duduk di samping kiri Abu Bakar" جََسَن عَنْ يَسَارِ أَبْي بَكْرِ Intinya, dalam hadis Bukhari nomor 664 tersebut tidak ada kalimat عَنْ يَيْنِ. Ini artinya bahwa Jalal telah berdusta dan melakukan manipulasi data, mengatakan kalimat عَنْ َيَِيْنِ sebagai bagian dari matan hadis Bukhari nomor 664 padahal sebenarnya tidak ada. Badruddin Al-'Aini mengatakan, "Sesungguhya (Rasulullah) tidak duduk di samping kanan (Abu Bakar), karena samping kiri adalah arah kamar beliau, dimana beliau merasa ringan untuknya (salat di samping kiri Abu Bakar)". ${ }^{13}$

Ketiga, kecerobohan Jalal dalam mengartikan kalimat. Menurut Jalal, kalimat حِذَاءَ, yang ada dalam rangkaian matan hadis Bukhari nomor 683 artinya adalah "di depan”. Jika حِذَاء artinya di depan, tentu hal ini sangat bertentangan dengan redaksi hadis Bukhari nomor 713 yang mengatakan bahwa Rasulullah duduk di sisi kiri Abu Bakar عَن يَسَارِ أَبِى بَكْرِ Padahal kalimat yang lengkapnya

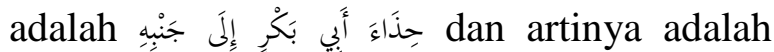
"duduk di sisi Abu Bakar sejajar di sampingnya". Bila artinya adalah "di sisi", maka hadis nomor 644 ini tidak bertentangan dengan hadis nomor 713, tetapi sebaliknya, kalimat hidzâ'a abî bakrin ilâ janbihi جَذَاءَ أَبِي

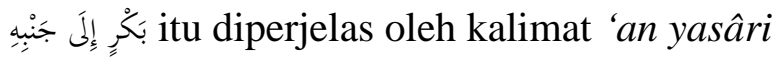

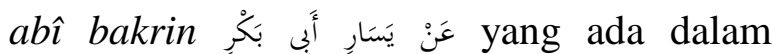
redaksi hadis nomor 713. Bila diterjemahkan secara lafzhiyyah, memang benar حِذَاًَ artinya adalah di depan, ${ }^{14}$ namun yang peru dicermati bahwa bunyi kalimat tersebut

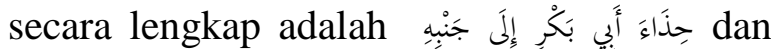

${ }^{13}$ (Al-suyuti, n.d., p. 92)

${ }^{14}$ Lois Ma'luf, Al-Munjid (Beirut: Al-Maktabah al-syarkiah, 1986), p. 123.; Kamus al-'Ashri Atabik 'Ali, Kamus Al-'Ashri (Yogyakarta: Yayasan Ali Maksum Ma'had Krapyak, 1996), p. 748. 
artinya adalah di samping. ${ }^{15}$ Oleh karenanya, mengartikan kalimat tersebut secara lengkap adalah hal yang paling sempurna dan logis untuk dipahami.

\section{Argumen kedua}

Ibnu Hajar mengatakan bahwa asy-Syafi'i dengan gamblang menyatakan bahwasannya Rasulullah hanya sekali mengimami salat setelah beliau menderita sakit, dan salat inilah yang beliau kerjakan sambil duduk. Pada awalnya salat tersebut diimami oleh Abu Bakar, lalu ia menjadi makmum yang memperdengarkan takbir Rasulullah kepada jama'ah. ${ }^{16}$ Selain itu, hadis ini juga dijadikan dalil sahnya salat imam yang salat sambil duduk karena suatu sebab, baik para makmumnya salat sambil duduk maupun sambil berdiri. ${ }^{17}$

\section{Argumen ketiga}

Dalam kontradiksi yang ketiga Jalal memberikan statemen bahwa hadis-hadis yang menceritakan Abu Bakar menjadi imam salat sulit untuk dipahami karena hadis-hadis tersebut sukar didamaikan, makanya tidak mudah untuk mencerna maknanya. Menurut Jalal hadis-hadis tersebut sulit dipahami karena ada beberapa alasan. Pertama, dalam satu riwayat dikatakan bahwa Rasulullah tidak ikut salat. Beliau hanya membuka tirai saja, karena beliau sakit parah. Abu Bakar yang saat itu jadi imam hendak mundur karena melihat Rasulullah datang. Kata Rasulullah, 'Teruskan saja!' Kedua, dalam riwayat yang lain dikatakan bahwa Abu Bakar mundur, kemudian Rasulullah maju dan menjadi imam. Rasulullah duduk sebagai imam dan Abu Bakar berdiri sebagai makmumnya.

Kedua hadis tersebut diriwayatkan oleh Imam Bukhari dalam Kitab al-adzan bab ahli ilmu dan orang mulia yang lebih utama untuk menjadi imam nomor 680 dan 681, dan

15 Abu al-Fadl Ahmad bin 'Ali bin Hajr Al'Asqalânî, Hadyu as-Sârî Muqaddimah Fath Al-Bârî (Riyadh: Dâr as-Salâm, 2000), p. 149.

16 Abu al-Fadl Ahmad bin 'Ali bin Hajr Al'Asqalânî, Fath Al-Bârî, ed. by Abu Qutaibah Nadhr Muhammad Al-Faryabi (Dar Thayibah), II, p. 226.

17 Al-‘Asqalânî, II, p. 227. keduanya menceritakan tentang apa yang dilakukan oleh Rasulullah beberapa saat menjelang wafatnya. Sementara hadis-hadis yang menceritakan tentang Rasulullah menjadi imam sebagaimana yang dimaksud oleh Jalal, Imam Bukhari meriwayatkannya dalam tiga tempat, yaitu hadis nomor 664, 683 dan 713.

Bila kelima hadis tersebut diperhatikan secara seksama, maka sebenarnya tidak ada kontradiksi yang menyebabkan hadis-hadis itu sulit untuk dipahami. Hadis-hadis yang dimaksud sebenarnya lebih menceritakan tentang peristiwa yang berbeda satu dengan yang lainnya. Kedua hadis pertama (riwayat Bukhari nomor 680 \& 681) menceritakan tentang kondisi Rasulullah beberapa saat sebelum beliau wafat. Dalam kedua hadis itu diriwayatkan bahwa ketika Abu Bakar sedang mengimami salat, tiba-tiba Rasulullah membuka tirai kamarnya dan menengok kepada para sahabat yang saat itu sedang salat. Lalu Abu Bakar hendak mundur dari posisinya karena menyangka bahwa Rasulullah akan ikut salat, tetapi Rasulullah mengisyaratkan supaya mereka tetap melanjutkan salat. Lalu beliau menutup kembali tirai kamarnya. Dan sejak saat itu para sahabat tidak bertemu lagi dengan Rasulullah.

Sementara ketiga hadis berikutnya (riwayat Bukhari nomor 664, 683 \& 713) menceritakan bahwa ketika Rasulullah sakitnya terasa parah lalu beliau menyuruh Abu Bakar untuk menjadi imam salat. Dan setelah beliau merasa agak lebih baik, lalu beliau masuk mesjid dengan dipapah oleh dua orang sahabat (Ali bin Abi Thalib dan Ibn 'Abbas). Saat itu Abu Bakar hendak mundur, tetapi Rasulullah mengisyaratkan untuk tetap di tempatnya. Kemudian beliau duduk di samping kiri Abu Bakar. Rasulullah menjadi imam sambil duduk sementara Abu Bakar bermakmum kepada Rasulullah sambil berdiri, dan orang-orang bermakmum kepada Abu Bakar.

Hadis-hadis tersebut sebenarnya tidak terlihat kontradiksi karena masing-masing hadis menceritakan kondisi dan peristiwa yang berbeda, meskipun tema yang diceritakan dalam hadis-hadis tersebut sama. 
Oleh karenanya, Jalal keliru jika mengatakan hadis-hadis tersebut tidak bisa diterima keabsahannya karena dianggap sebagai hadis mudhtharib.

Ada beberapa alasan kenapa hadis tersebut tidak disebut sebagai hadis mudhtharib. Pertama, hadis-hadis tersebut diriwayatkan dari sahabat yang berbeda, meskipun derajat hadisnya sama-sama shahih. Dua hadis pertama (riwayat Bukhari nomor 680 \& 681) diriwayatkan dari Anas bin Malik, sementara ketiga hadis berikutnya semuanya diriwayatkan dari Aisyah (riwayat Bukhari nomor 664, 683 \& 713). Jika melihat konsep hadis mudhtharib yang telah dirumuskan para ahli hadis, maka hal ini sebenarnya tidak memenuhi syarat hadis mudhtahrib. Suatu hadis dianggap muhtharib jika ada dua tema riwayat yang sama tetapi redaksinya berbeda, atau satu rawi menceritakan redaksi hadis yang berbeda padahal tema peristiwa yang diceritakannya sama. ${ }^{18}$ Logikanya, jika dua orang berbeda menceritakan peristiwa yang berbeda pula, maka sejatinya hal itu tidak disebut berita yang kontradiksi.

Kedua, matan/redaksi hadis yang dibicarakan berbeda. Seperti yang telah dijelaskan sebelumnya bahwa hadis-hadis tersebut menceritakan tentang dua peristiwa yang berbeda, meskipun semuanya memiliki kesamaan dalam hal tema yang dibicarakan, yaitu peristiwa yang terjadi beberapa hari sebelum Rasulullah wafat. Hadis yang diriwayatkan oleh Aisyah menceritakan tentang penunjukkan Abu Bakar sebagai imam salat di saat Rasulullah mulai merasakan sakitnya bertambah parah. Sementara hadis yang diriwayatkan oleh Anas bin Malik menceritakan tentang masamasa terakhir Rasulullah beberapa saat sebelum beliau wafat.

Ketiga, waktu kejadian yang diceritakan juga berbeda. Supaya bisa dibedakan kapan waktu terjadinya masing-masing dari peristiwa tersebut, bisa kita lihat penuturan Ibnu Katsir dalam Al-Bidâyah wa an-

${ }^{18}$ Asy-Syahrazuri, p. 124. Lihat juga Al-Azhari, p. 240.
Nihâyah. ${ }^{19}$ Ibnu Katsir menyebutkan bahwa pada hari Kamis lima hari menjelang wafat, Rasulullah menyampaikan khutbah agung yang menerangkan keutamaan Abu Bakar dibandingkan seluruh sahabat yang lainnya. Mungkin khutbah ini merupakan pengganti dari keinginan beliau untuk menuliskan wasiat tentang siapa yang akan menjadi penggantinya. Dalam khutbah ini Rasulullah mandi terlebih dahulu, kemudian keluar untuk salat bersama kaum muslimin kemudian beliau menyampaikan khutbahnya. ${ }^{20}$

Menurut Ibn Katsir ini merupakan dalil yang paling jelas bahwa Nabi tidak salat shubuh pada hari Senin bersama para sahabat. Dan beliau tidak dapat keluar rumah selama tiga hari. Dengan demikian dapat kita katakan bahwa salat beliau terakhir bersama jama'ah adalah salat Zhuhur, sebagaimana yang dijelaskan dalam hadis Aisyah. Dan hari itu adalah hari Kamis, bukan hari Sabtu dan bukan hari Ahad, sebagaimana yang diceritakan oleh Al-Baihaqi dari Maghazi Musa bin 'Uqbah sehingga keterangan itu lemah, berdasarkan apa yang telah kami terangkan tentang khutbah beliau sesudah itu dan disebabkan beliau tidak menemui orangorang sejak hari Jum'at, Sabtu dan Ahad, sehingga itu adalah tiga hari berturut-turut". ${ }^{21}$ Rasulullah wafat pada hari Senin 12 Rabiul Aawwal, ${ }^{22}$ dan dikuburkan pada hari Rabu. ${ }^{23}$

Bila merujuk pada penjelasan Ibnu Katsir di atas, maka kronologis peristiwa yang terjadi di antara Rasululah dan Abu Bakar itu bisa dirunut sebagai berikut: Ketika sakit Nabi bertambah parah, maka beliau menyuruh Abu Bakar untuk mengimami salat. Lalu Abu Bakar mengimami salat para

19 'Imâd ad-Dîn Abû al-Fidâ bin Katsîr AdDimasyqî, Al-Bidâyah Wa an-Nihâyah, ed. by 'Alî Syairî (Beirut: Dâr Ihyâ at-Turâts al-'Arabî, 1988), V, p. 523.

${ }^{20}$ Ad-Dimasyqî, v, p. 249.

${ }^{21}$ Ad-Dimasyqî, v, p. 55.

22 'Izzuddîn Abû Hasan 'Alî bin Abî al-Kiram bin Atsîr Asy-Syaibânî, Al-Kâmil Fî at-Târîkh, ed. by Abû al-Fidâ 'Abdullâh Al-Qâdhî (Beirut: Dâr al-Kutub al'Ilmiyyah, 1987), II, p. 187.

${ }^{23}$ Keterangan ini adalah satu-satunya riwayat yang terdapat dalam Musnad Imam Ahmad pada Musnad 'Aisyah dengan nomor hadis 24790. 
sahabat dalam beberapa kesempatan selama beberapa hari. Karena sakit beliau mulai terasa ringan, dalam suatu kesempatan beliau ikut bergabung salat berjama'ah. Pada salat tersebut beliau menempati posisi Abu Bakar yang saat itu menjadi imam. Dalam salat ini juga beliau bertindak sebagai imam dalam keadaan duduk. Dan ini merupakan satusatunya salat berjama'ah yang diimami oleh Rasulullah dalam kedaan duduk. ${ }^{24}$ Pada shubuh hari Senin beliau menengok para sahabat dari kamar Aisyah yang pada saat itu mereka sedang salat shubuh berjama'ah dipimpin oleh Abu Bakar. Beliau tidak ikut salat, lalu menutupkan kembali tirai kamar Aisyah yang sebelumnya beliau singkapkan. Lalu pada siang harinya beliau wafat, dan tidak sempat lagi bertemu dengan para sahabat.

Jika Jalal mengatakan bahwa peristiwa tersebut kontradiksi karena hadis-hadisnya menceritakan dua kondisi yang berlainan dan ia beralasan bahwa satu riwayat mengatakan yang jadi imam adalah Abu Bakar, sementara riwayat lain mengatakan yang jadi imam adalah Rasulullah hal tersebut tidaklah benar. Hadis-hadis di atas memang menceritakan dua kondisi berbeda dan terjadi pada orang yang berbeda pula. Tetapi masing-masing riwayat tersebut terjadi pada waktu yang berlainan satu sama lainnya, oleh karena itu kedua hadis tersebut harus dipahami secara proporsioal sesuai tempatnya masing-masing. Hal ini sesuai dengan apa yang dikatakan oleh al-'Ainî, "Kedua hadis ini tidak berlawanan dan tidak bertentangan, tidak pula ada yang menjadi nasikh atau mansukh, akan tetapi mujmal mufassir. Dan jika yang satu terhadap yang lainnya digabung, maka

\footnotetext{
${ }^{24}$ Al-'Aini mengatakan bahwa salat yang diimami oleh Nabi ini adalah salat zhuhur hari Sabtu atau Ahad. Lihat Badruddin Al-'Aini, Umdah Al-Qari Syarh Shahih Al-Bukhar (Beirut: Dar Kutub al'Ilmiyyah, 2001), V, p. 279. Ketidakpastian al-'Aini dalam menyebutkan hari sangat beralasan, karena memang tidak ada riwayat yang mengatakan pada hari apa Nabi menjadi imam salat dalam keadaan duduk. Sementara waktunya salatnya disebutkan, yaitu salat zhuhur. Mengenai penjelasan hal ini, lihat Abu al-Fadl Ahmad bin 'Ali bin Hajr Al-'Asqalânî, Fath Al-Bârî, ed. by Abu Qutaibah Nadhr Muhammad Al-Faryabi (Dar Thayibah), II, p. 227.
}

gugurlah pertentangan di antara keduanya, makanya setiap khabar tersebut harus dipahami sesuai tempatnya". ${ }^{25}$

\section{Argumen keempat}

Dalam hadis Bukhari nomor 3667 disebutkan oleh siti Aisyah bahwa Rasulullah wafat, sementara Abu Bakar berada di Sunh, sebuah tempat kira-kira beberapa puluh kilometer di luar kota Madinah. Jadi, pada hari-hari terakhir Rasulullah, Abu Bakar tidak berada di Madinah. Karena itu peristiwa Abu Bakar menjadi imam salat agak diragukan terjadinya. Abu Bakar tidak berada di Madinah pada hari-hari terakhir Rasulullah. Ini menurut Siti Aisyah yang justru menceritakan peristiwa salat itu. Jadi orang yang sama bercerita pada satu riwayat Abu Bakar tidak berada di Madinah dan pada riwayat yang lain ia berada di Madinah. ${ }^{26}$

Merujuk kepada penuturan Ibn Katsir dan al-Kandahlawi, ${ }^{27}$ maka asumsi Jalal yang mengatakan bahwa peristiwa Abu Bakar yang menjadi imam itu diragukan kebenarannya, karena di saat Rasulullah wafat ia ada di Sunh, hal tersebut jelas sangat keliru. Kekeliruan Jalal ini setidaknya bisa dijelaskan melalui dua alasan berikut ini. Pertama, Ibnu Katsir menjelaskan bahwa Rasulullah menunjuk Abu Bakar sebagai imam salat itu terhitung sejak salat ashar hari Kamis hingga salat shubuh hari Senin. ${ }^{28}$ Jika dihitung, berarti Abu Bakar menggantikan Rasulullah itu sebanyak 19 kali, yaitu ashar, maghrib dan isya (hari Kamis), shubuh, zhuhur, ashar, maghrib, isya (hari Jum'at), shubuh, zhuhur, ashar, maghrib, isya (hari Sabtu), shubuh, zhuhur, ashar, maghrib, isya (hari Ahad) dan shubuh hari Senin. Berdasarkan hadis yang diriwayatkan dari Anas bin Malik disebutkan bahwa Rasulullah wafat pada hari senin. ${ }^{29}$ Ibnu Sa'ad mengatakan, "Beliau wafat ketika matahari

${ }^{25}$ Al-'Aini, XII, pp. 274-75.

${ }^{26}$ Rakhmat, pp. 92-93.

${ }^{27}$ Ad-Dimasyqî, v, p. 265.;Muhammad Yûsuf bin Muhammad Ismâ'̂̂l Al-Kandahlawî, Hayâh AshShahâbah, ed. by Basyâr 'Awwâd Ma'rûf (Beirut: Muassasah ar-Risâlah, 1999), II, p. 18.

${ }^{28}$ Ad-Dimasyqî, v, p. 55.

${ }^{29}$ Shahih al-Bukhari, hadis no. 680. 
posisi condong". Sementara Ad-Dawadi mengatakan bahwa beliau wafat sebelum tengah hari. ${ }^{30}$

Ini artinya bahwa Abu Bakar menjadi imam itu terhitung selama lima hari, dan salat terakhir yang diimami oleh Abu Bakar adalah salat shubuh hari Senin. Hal ini berdasarkan hadis yang diriwayatkan dari Anas bin Malik. ${ }^{31}$ Ibnu Rajab mengatakan bahwa salat yang diimami oleh Abu Bakar tersebut adalah salah shubuh; hari Senin, dan salat itu adalah salat terakhir yang disaksikan oleh Nabi di akhir hidupnya. ${ }^{32}$ Ia juga mengatakan bahwa zhahir hadis tersebut menunjukkan bahwa Rasulullah tidak pergi ke masjid untuk salat berjama'ah pada saat itu, tidak menjadi imam tidak juga sebagai makmum. ${ }^{33}$

Sementara keberadaan Abu Bakar di Sunh adalah untuk menemui salah satu istrinya, yaitu Habibah binti Kharijah. Ibnu Katsir mengatakan kepergian Abu Bakar ke tempat tersebut adalah setelah beliau selesai mengimami salat, yaitu salat shubuh. Selengkapnya bisa dilihat penuturan Ibnu Katsir berikut ini, "Ketika Abu Bakar selesai dari salat, maka beliau masuk menghadap Rasulullah dan berkata kepada Aisyah, "Aku rasa sakit Rasulullah telah sembuh". Dan hari itu adalah giliran putri Kharijah, yaitu salah seorang istri Abu Bakar yang tinggal di Sunh, arah sebelah timur Madinah. Lalu beliau segera menaiki kudanya dan berangkat ke sana". ${ }^{34}$ Al-Kandahlawi mengatakan bahwa saat itu Abu Bakar terlebih dahulu meminta izin kepada Nabi dan beliau pun

30 Badruddin Al-'Aini, Umdah Al-Qari Syarh Shahih Al-Bukhar (Beirut: Dar Kutub al-'Ilmiyyah, 2001), VI, p. 5. Lihat juga Abu al-Fadl Ahmad bin 'Ali bin Hajr Al-'Asqalânî, Fath Al-Bârî, ed. by Abu Qutaibah Nadhr Muhammad Al-Faryabi (Dar Thayibah), VIII, p. 180

${ }^{31}$ Shahih al-Bukhari, hadis no. 680.

${ }^{32}$ Ibn Rajab al-Hanbali, Fath Al-Bari Syarh Shahih Al-Bukhari (Madinah: Maktabah al-Ghuraba alAsariyyah, 1996),VI, p. 117.

33 Ibnu Rajab Al-Hanbali, Fath al-Bâri Syarh Shahih al-Bukhari, juz VI, 117.

${ }^{34}$ Ad-Dimasyqî, v, p. 265. mengizinkan Abu Bakar untuk menemui istrinya. ${ }^{35}$

Dokumentasi Ibnu Katsir dan AlKandahlawi ini intinya menjelaskan bahwa Abu Bakar pergi ke Sunh itu adalah setelah beliau beres mengimami salat shubuh, dan itu adalah hari Senin. Oleh karena itu, keberadaan Abu Bakar di Sunh tidak bertentangan dengan waktu Abu Bakar ketika ia menjadi imam salat, karena kedua peristiwa ini terjadi pada waktu dan tempat yang berbeda. Singkatnya, Abu Bakar menjadi imam itu terhitung sejak salat ashar hari Kamis hingga shubuh hari Senin, sedangkan pergi ke Sunh adalah setelah beliau selesai mengimam salat shubuh hari Senin.

Kedua, Jalal mengatakan bahwa Sunh adalah sebuah tempat kira-kira beberapa puluh kilometer di luar kota Madinah. Untuk lebih jelasnya, deskripsi yang lebih jelas mengenai Sunh ini bisa kita rujuk dalam beberapa kitab mu'jam al-balad (ensiklopedi tempat). Sunh adalah nama sebuah tempat di Madinah, ${ }^{36}$ yaitu tempat bermukimnya Bani

35 Al-Kandahlawî, II, p. 18. Lihat jugaAbû Muhammad 'Abd al-Malik bin Hisyâm Al-Muâfirî, As-Sîrah an-Nabawiyyah Li Ibnu Hisyâm, ed. by Mushthafâ As-Saqâ (kairo: Syirkah Maktabah Mushthafâ al-Bâbi al-Halabî, 1995), II, p. 654.;Abû arRabî’ Sulaimân bin Mûsâ Al-Humairî, Al-Iktifâ Bimâ Tadhammanah Min Maghâzî Rasulillâh Wa AtsTsalâsah Al-Khulafâ (Beirut: Dâr al-Kutub al'Ilmiyyah, 1999), II, p. 44.;Muhammad bin Yûsuf ashShâlhî Asy-Syâmî, Subul Al-Hady Wa Ar-Rasyâd Fî̀ Sirrah Khair Al-'Ibâd, ed. by Syaikh 'Âdil Ahmad 'Abd Al-Maujûd (Beirut: Dar al-Kutub al-'Ilmiyyah, 1993), XII, P. 245.;Husain bin Muhammad al-Hasan ad-Diyâr Bakrî, Târîkh Al-Khamîs Fî Ahwâl Anfus anNafîs (Beirut: Dâr Shâdir), II, p. 163.; Muhammad bin 'Abd al-Wahhab An-Najdî, Mukhtashar Sîrah ArRasûl Shallallahu 'alaihi Wa Sallam (Riyadh: Wizârah asy-Syu'ûn al-Isliyyah wa al-Auqâf wa adDa'wah wa al-Irsyâd, 1997), p. 246.

${ }^{36}$ Al-Harabi mengatakan bahwa cara membacanya adalah dengan mendhamahkan huruf 'sin'

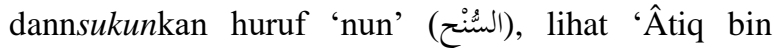
Ghaits Al-Harabî, Mu'jam Al-Ma'âlim AlJugrâfiyyaah Fi as-Sîroh an-Nabawiyyah (makah al mukarommah: Dâr Makkah, 1982), p. 162. Sementara Abû 'Ubaid al-Andalusî dan Muhammad Hasan Syurrâb membacanya dengan mendhamahkan huruf 'sin' dan huruf 'nun' (السُشُّ), lihat Abû 'Ubaid 'Abd Allâh Al-Andalusî, Mu'jam Mâ Ista'jam Min Asmâ' 
al-ㅂârits bin Khazrâj dan termasuk di antara salah satu dataran tinggi yang ada di Madinah. ${ }^{37}$ Sunh terletak di pinggiran Madinah sebelah timur, sementara dari arah masjid Nabi letaknya berada di arah timur laut ${ }^{38}$ dan jaraknya dari masjid nabi adalah satu mil $(1,609 \mathrm{~km}) .{ }^{39}$

Jika memerhatikan penjelasan di atas, maka sangat mungkin sekali ketika Abu Bakar diberitahu tentang wafatnya Rasulullah ia bisa sampai di rumah Rasulullah dalam waktu yang sangat singkat, mengingat bahwa jarak antara masjid Nabi dan Sunh hanyalah satu mil. ${ }^{40}$ Padahal, sebelum pergi ke Sunh Abu Bakar masih berada di rumah Nabi, dimana sebelumnya ia terlebih dahulu memimpin salat shubuh berjama'ah. Hal ini membuktikan bahwa asumsi Jalal yang mengatakan bahwa Aisyah menceritakan dua peristiwa yang kontradiksi jelas sangat keliru. Karena peristiwa yang diceritakan oleh Aisyah tersebut pada hakikatnya terjadi pada waktu yang berbeda.

\section{Indikasi kelima}

Pernyataan Jalal terlalu berlebihan dalam menjustifikasi untuk mengatakan bahwa hampir seluruh kitab tarikh menyebutkan bahwa Abu Bakar pada hari-hari terakhir Rasulullah berada dalam pasukan Usamah. Untuk mengklarifikasi ucapan Jalal tersebut, ada baiknya kalau kita perhatikan penuturan Ibnu Katsir berikut ini:

"Sebelum Rasulullah wafat, beliau telah memerintahkan pasukan Usamah agar berjalan menuju tanah al-Balqa yang berada di Syam, persisnya di tempat

Al-Bilâd Wa Al-Mawâdhi' (Beirut: 'âlam al-Kutub, 1982), III, p. 760. dan Al-Humairî, II, p. 325; Muhammad bin Muhammad Hasan Syurrâb, AlMa'âlim Al-Atsîrah Fî̀ as-Sunnah Wa as-Sirâh (Beirut: Dâr al-Qalam, 1990), p. 144.

37 Abû 'Abdullah Muhammad Al-Humairî, ArRaudh Al-Mu'thar Fî Khabar Al- 'Aqthâr, ed. by Ihsân 'Abbâs (Beirut: Muassasah Nâshir li ats-Tsaqâfah, 1980), p. 325

${ }^{38}$ Al-Harabî, p. 162

${ }^{39}$ Al-Harabî, p. 162. lihat juga Al-Andalusî, III, p. 760.

40 Al-Harabi mengatakan bahwa antara Sunh dan Madinah itu tidak jauh dari tempat yang dikenal sekarang. terbunuhnya Zaid bin Haritsah, Ja'far dan Abdullah bin Rahawah. Dengan misi agar pasukan Usamah segera menaklukkan wilayah tersebut. Maka berangkatlah pasukan Usamah ke Jurf dan mendirikan perkemahan di sana. Di antara pasukan tersebut terdapat Umar bin Khattab dan ada pula yang mengatakan bahwa Abu bakar turut pula di situ, namun Rasulullah mengecualikannya untuk menjadi imam salat". 41

Sementara Ibnu Hajar menyebutkan dalam Fath al-Bari bahwa Ibnu Taimiyyah dalam kitabnya Ar-Radd 'ala Ibn al-Muthahhir menolak jika Abu Bakar dan Umar termasuk dalam pasukan Usamah. Ia berpendapat bahwa Abu Bakar tidak ikut dalam pasukan Usamah disebabkan Nabi baru mengangkat Usamah sebagai panglima pasukan setelah beliau sakit dan beberapa hari sebelum wafatnya, sementara Rasulullah telah memerintahkan Abu Bakar untuk menjadi imam salat di masjid. ${ }^{42}$

Dalam Al-Bidayah wa an-Nihayah, Ibnu Katsir berkata, "Nabi telah memerintahkan untuk mengikuti pasukan ini sebagian besar sahabat yang senior-baik dari Muhajirin maupun Anshor - untuk turut dalam pasukan Usamah, dan termasuk dari sekian sahabat yang senior adalah Umar bin Khattab. Maka barangsiapa berkata, sesungguhnya Abu Bakar masuk dalam rombongan pasukan ini maka telah keliru, sebab ketika sakit Rasulullah memuncak, pasukan Usamah masih berada di Jurf dan Nabi sw telah memerintahkan supaya menjadi imam salat. Bagaimana mungkin Abu Bakar masuk dalam pasukan Usamah sementara ia adalah imam kaum Muslimin dalam salat dengan izin Rasulullah. Andai saja ia memang turut pasukan Usamah maka nash syariat telah

41 'Imâd ad-Dîn Abû al-Fidâ bin Katsîr AdDimasyqî, Al-Bidâyah Wa an-Nihâyah, ed. by 'Alî Syairî (Beirut: Dâr Ihyâ at-Turâts al-'Arabî, 1988), VI, p. 335.

${ }^{42} \mathrm{Abu}$ al-Fadl Ahmad bin 'Ali bin Hajr Al'Asqalânî, Fath Al-Bârî, ed. by Abu Qutaibah Nadhr Muhammad Al-Faryabi (Dar Thayibah), VIII, p. 191. 
mengecualikannya dari seluruh sahabat yang ikut di bawah komando Usamah". ${ }^{43}$

Pernyataan Ibnu Katsir berikut ini akan lebih memperjelas lagi dimana sebenarnya posisi Abu Bakar ketika kaum muslimin melakukan ekspedisi di bawah komando Usamah. "Di antara negeri yang tetap istiqamah di atas Islam adalah negeri Tsaqif di Tha'if. Mereka tidak lari dan tidak pula murtad. Ketika berbagai masalah besar ini terjadi, banyak orang-orang mengusulkan kepada Abu Bakar agar menunda keberangkatan pasukan Usamah, karena umat membutuhkan mereka untuk mengatasi masalah yang lebih penting. Dengan alasan bahwa pasukan yang disiapkan Nabi tersebut sebelumnya dipersiapkan ketika negara Islam Madinah dalam kondisi aman. Termasuk di antara orang yang mengajukan usul tersebut adalah Umar, ia mengusulkan penundaan keberangkatan pasukan Usamah itu. Namun Abu Bakar dengan tegas menolak saran tersebut. Ia berpendapat harus tetap menyegerakan keberangkatan pasukan Usamah. Sampai-sampai beliau bersumpah, 'Demi Allah, aku tidak akan melepas buhul yang telah diikat oleh Rasulullah, walaupun burung menyambar kita dan seluruh binatang buas di sekitar Madinah menyerang kita, bahkan sekalipun anjing-anjing mengejar kaki-kaki ummmahtul mukminin-istri-istri Rasulullah-aku akan tetap menjalankan misi pasukan Usamah. Dan aku juga akan memerintahkan agar orang-orang tetap berjaga di sekitar Madinah". ${ }^{4}$

Dan ternyata berangkatnya pasukan Usamah membawa kemaslahatan besar, setiap kali mereka melewati perkampungan Arab, pasti akan menimbulkan rasa gentar mereka untuk memberontak, sehingga ada yang berkata, "Tidak mungkin pasukan sebesar ini keluar kecuali mereka telah memiliki pertahanan yang kuat di Madinah".

\footnotetext{
${ }^{43}$ 'Imâd ad-Dîn Abû al-Fidâ bin Katsîr AdDimasyqî, Al-Bidâyah Wa an-Nihâyah, ed. by 'Alî Syairî (Beirut: Dâr Ihyâ at-Turâts al-‘Arabî, 1988), VI, p. 335 .

44 'Imâd ad-Dîn Abû al-Fidâ bin Katsîr AdDimasyqî, Al-Bidâyah Wa an-Nihâyah, ed. by 'Alî Syairî (Beirut: Dâr Ihyâ at-Turâts al-'Arabî, 1988), VI, p. 335 .
}

Dan setelah empat puluh hari atau tujuh puluh hari mereka pulang membawa kemenangan dan harta rampasan perang. ${ }^{45}$

Ath-Thabari mengatakan dalam Tarikhnya, "Saif bin Umar meriwayatkan dari Abu Dhamrah, Abu 'Amr dan lainlainnya dari al-Hasan al-Bashri, 'Ketika Abu Bakar bersiap-siap memberangkatkan pasukan Usamah, sebagian kaum Anshar berkata kepada Umar, 'Katakan padanya agar mengganti dan tidak menunjuk Usamah sebagai pimpinan kita'. Maka Umar pun segera melaporkan hal itu kepada Abu Bakar. Maka diceritakan bahwa Abu Bakar menarik janggut Umar dan berkata, 'Payah-payah ibumu mengandungmu wahai Umar bin alKhattab, bagaimana mungkin aku mengganti pimpinan yang telah ditunjuk oleh Rasulullah'. Kemudian Abu Bakar segera bangkit dan berjalan sendiri menuju Jurf untuk memeriksa pasukan Usamah dan memerintahkan mereka untuk mulai berjalan, sementara beliau turut berjalan kaki mengiringi mereka, sedangkan Usamah menaiki kendaraan dan 'Abdurrahman memegang tali kekang unta Abu Bakar. Usamah berkata, 'Wahai khalifah Rasulullah, naiklah ke atas kendaraan ini atau aku yang turun!' Abu Bakar menjawab, 'Demi Allah, aku tidak akan naik dan engkau tidak boleh turun!' Setelah itu Abu Bakar memohon agar Umar bin Khattab dibebastugaskan untuk menemaninya di Madinah, maka Usamah pun mengabulkannya. ${ }^{46}$

Beberapa keterangan di atas menjadi penjelas bahwa Abu Bakar tidak termasuk dari bagian pasukan yang dipimpin oleh Usamah sebagaimana yang dikatakan Jalal. Oleh karenanya, Abu Bakar tidak berada di Jurf, karena pada saat itu ia ditugaskan oleh Rasulullah untuk menjadi imam salat di Madinah. Kalaupun Abu Bakar berada di Jurf, itu adalah untuk memeriksa kondisi pasukan Usamah, dan saat itu posisi Abu

45 'Imâd ad-Dîn Abû al-Fidâ bin Katsîr AdDimasyqî, Al-Bidâyah Wa an-Nihâyah, ed. by 'Alî Syairî (Beirut: Dâr Ihyâ at-Turâts al-'Arabî, 1988), VI, p. 335.

${ }^{46} \mathrm{Abu}$ Ja'far Jarir Ath-Thabari, Târîkh AthThabarî, ed. by Shidqi Jamîl Al-'Athâr (Beirut: Dâr al-Fikr, 1998), III, p. 268. 
Bakar adalah sebagai khalifah, menggantikan Rasulullah, bukan sebagai bagian dari pasukan Usamah. Abu Bakar pergi ke Jurf itu setelah Rasulullah wafat.

Dengan demikian asumsi Jalal jelas-jelas sangat keliru, karena peristiwa Abu Bakar menjadi imam salat dan kunjungan beliau kepada pasukan Usamah yang sedang berada di Jurf terjadi dalam waktu yang berbeda. Abu Bakar menjadi imam di saat Rasulullah masih hidup, sementara Abu Bakar mengontrol pasukan Usamah adalah di saat Rasulullah sudah wafat. Dengan demikian, tidak ada kontradiski dalam kedua peristiwa tersebut.

\section{Indikasi keenam}

Pada satu riwayat Rasulullah menyuruh Abu Bakar menjadi imam salat berjama'ah (lihat hadis Bukhari nomor 680 dan 681) sedangkan pada riwayat yang lain Rasulullah menjadi imam (lihat kontradiksi nomor 2). ${ }^{47}$

Kedua hadis di atas diriwayatkan oleh Bukhari dalam kitab adzan bab "orang yang punya ilmu dan keutamaan lebih berhak menjadi imam" dan keduanya menceritakan tentang apa yang terjadi beberapa saat sebelum Rasulullah wafat. Jalal menganggap hadis-hadis tersebut sebagai justifikasi bahwa hadis-hadis tentang Abu Bakar menjadi imam salat itu hadis-hadisnya kontradiksi. Ia menganggap kontradiksi karena dalam kedua hadis tersebut sang rawi hadis (Anas bin Malik) mengatakan bahwa ketika Rasulullah akit, Abu Bakarlah yang saat itu menjadi imam. Dalam hadis Bukhari nomor 680 Anas mengatakan bahwa Abu Bakar pernah mengimami mereka salat di saat sakitnya Nabi yang membawanya pada kewafatannya. Sedangkan pada hadis nomor 681 ia mengatakan, "Nabi tiga hari tidak keluar rumah untuk salat. Dan selama itu salat dilaksanakan dengan Abu Bakar sebagai imam salat". Sementara dalam hadis Bukhari nomor 664, 683 dan 713 dikatakan bahwa selama Rasulullah sakit, beliau juga pernah menjadi imam salat.

Menurut Jalal, ketiga hadis ini (Shahih Bukhari nomor 644, 683 \& 713) maknanya

\footnotetext{
${ }^{47}$ Rakhmat, p. 93.
}

bertentangan dengan dua hadis yang sebelumnya telah disebutkan (Shahih Bukhari nomor 680 \& 681).

Bila kembali merujuk pada pernyataan Ibnu Katsir maka kita akan mendapatkan penjelasan bahwa Rasulullah menunjuk Abu Bakar sebagai imam salat itu terhitung sejak salat ashar hari Kamis hingga salat shubuh hari Senin. ${ }^{48}$ Jika dihitung, berarti Abu Bakar menggantikan Rasulullah itu sebanyak 19 kali, ${ }^{49}$ yaitu ashar, maghrib dan isya (hari Kamis), shubuh, zhuhur, ashar, maghrib, isya (hari Jum'at), shubuh, zhuhur, ashar, maghrib, isya (hari Sabtu), shubuh, zhuhur, ashar, maghrib, isya (hari Ahad) dan shubuh hari Senin. Berdasarkan hadis yang diriwayatkan dari Anas bin Malik disebutkan bahwa Rasulullah wafat pada hari senin. ${ }^{50}$ Ini artinya bahwa Abu Bakar menjadi imam itu terhitung selama lima hari (Kamis, Jum'at, Sabtu, Ahad \& Senin), dan salat terakhir yang diimami oleh Abu Bakar adalah salat shubuh hari Senin.

Sementara hadis yang mengatakan bahwa ketika sakit Rasulullah juga pernah mengimami salat (Bukhari nomor 664, 683 \& 713), hadis tersebut sebenarnya tidak kontradiksi dengan hadis-hadis yang mengatakan bahwa Abu Bakar menjadi imam salat selama Rasulullah sakit (Bukhari nomor 680 \& 681). Jika Ibnu Katsir mengatakan bahwa Abu Bakar menjadi imam salat itu sebanyak sembilan belas kali, sementara beberapa hadis mengatakan bahwa Rasulullah juga selama sakitnya beliau pernah menjadi imam salat, yang dalam salat tersebut beliau menggantikan posisi $\mathrm{Abu}$

${ }^{48}$ Ibnu Katsîr, Al-Bidâyah wa an-Nihâyah, juz V, 249. Lihat juga Shahih al-Bukhari hadis nomor 681.

${ }^{49}$ Ibnu Atsir mengatakan bahwa Abu Bakar salat bersama kaum Muslimin itu sebanyak tujuh belas kali; lihat Ibnu Atsîr, Al-Kâmil fî at-Târîkh, juz II, 186. Penghitungan ini berbeda dengan yang dikatakan oleh Ibnu Katsir yang megatakan bahwa Abu Bakar menjadi imam salat itu sebanyak sembilan belas kali. Penghitungan Ibnu Atsir yang lebih sedikit ini bisa juga benar, jika ia menganggap bahwa satu waktu ketika Abu Bakar menjadi imam, tiba-tiba posisi ia digantikan oleh Rasulullah yang menjadi imam sambil duduk. Sehingga dalam peristiwa tersebut Ibnu Atsir tidak menghitung Abu Bakar sebagai imam sampai tuntas.

${ }^{50}$ Shahih al-Bukhari, hadis no. 680. 
Bakar, maka dengan demikian bisa dikatakan bahwa Abu Bakar menjadi imam salat itu jumlahnya kurang dari sembilan belas kali. Hal ini adalah berdasarkan hadis yang diriwayatkan dari Aisyah. ${ }^{51}$

Al-'Aini mengatakan bahwa salat yang diimami oleh Nabi ini adalah salat zhuhur hari Sabtu atau Ahad. ${ }^{52}$ Ketidakpastian al'Aini dalam menyebutkan harinya sangat beralasan, karena memang tidak ada riwayat yang mengatakan pada hari apa Nabi menjadi imam salat dalam keadaan duduk. Sementara waktunya salatnya disebutkan, yaitu salat zhuhur. ${ }^{53}$ Ibn Hajar mengatakan bahwa asySyafi'i dengan gamblang menyatakan bahwasanya Rasulullah hanya sekali mengimami salat setelah beliau menderita sakit, dan salat inilah yang beliau kerjakan sambil duduk. Pada awalnya salat tersebut diimami oleh Abu Bakar, lalu ia menjadi makmum yang memperdengarkan takbir Rasulullah (kepada jama'ah). Ia juga menegaskan bahwa Rasulullah tidak pernah mengimami para sahabat sambil duduk kecuali hanya sekali. ${ }^{54}$

Ini artinya bahwa Abu Bakar menjadi imam salat itu terhitung beberapa kali, sementara Rasulullah ketika beliau sakit, ia hanya menjadi imam salat sekali, itupun beliau lakukan dalam keadaan duduk. Dengan demikian asumsi Jalal yang mengatakan bahwa hadis-hadis tersebut kontradiksi jelas sangat keliru, karena pada kenyataannya hadis-hadis yang dimaksud oleh Jalal tidak terbukti ada ikhtilaf (perselisihan) di dalamnya. Oleh karenanya, riwayat-riwayat tersebut bisa dijadikan pegangan dan diakui kehujjahannya.

Ibnu Katsir mengutip perkataan $\mathrm{Abu}$ Hasan al-Asy'ari dalam kitab Ibânahnya, ${ }^{55}$ ia berkata, "Perintah Rasulullah memajukan Abu Bakar adalah suatu perkara yang

51 Shahih al-Bukhari, hadis no. 687; Musnad Ahmad, Musnad 'Aisyah no. 26137.

52 Badruddin Al-'Aini, Umdah Al-Qari Syarh Shahih Al-Bukhar (Beirut: Dar Kutub al-'Ilmiyyah, 2001), V, P. 279.

${ }^{53}$ Al-‘Asqalânî, II, p. 227.

54 Abu al-Fadl Ahmad bin 'Ali bin Hajr Al'Asqalânî, Fath Al-Bârî, ed. by Abu Qutaibah Nadhr Muhammad Al-Faryabi (Dar Thayibah), II. 227.

${ }^{55}$ Ad-Dimasyqî, v, p. 256. mendasar (dharuri) dalam agama Islam”. AlAsy'ari juga berkata, "Sikap Rasulullah ketika mengedepankan Abu Bakar sebagai imam salat adalah pertanda bahwa beliaulah orang yang paling alim dari seluruh sahabat dan yang paling baik bacaannya".

Ibnu Katsir berkata, "Ungkapan Abu Hasan al-Asy'ari ini sangat layak untuk ditulis dengan tinta emas. Dan seluruh kriteria imam terkumpul dalam sosok Abu Bakar ash-Shidiq. Salat Rasulullah di belakangnya dalam beberapa kesempatan tidak bertentangan dengan sebuah hadis shahih yang diriwayatkan bahwa Abu Bakar bermakmum di belakang Rasululah, karena hal tersebut terjadi dalam kesempatan lain." 56

Al-'Aini mengutip perkataan Nu'aim bin Abu Hind, ia mengatakan, "Beberapa riwayat yang datang menjelaskan kisah ini semuanya shahih, dan tidak ada pertentangan (ta'arudh) di dalamnya". ${ }^{57}$ Oleh karenanya, para ulama tidak mungkin mengambil hadis yang terbukti secara jelas kontra dengan al-Quran dan hadis yang mutawatir atau kontra dengan logika dan realita indra dan sulit untuk dicari titik temu, atau kontra dengan fakta sejarah yang sudah dikenal secara umum. Bagaimana mungkin mereka mampu membuat klasifikasi hadis lemah, munkar, maudhu', syadz, mu'allal dan mudhtharib kalau tidak mengkritisi matan hadis secara cermat dan akurat?! Ibnu Qayyim mengatakan, "Tidaklah terjadi pertentangan, berlawanan dan perselisihan di antara hadis-hadis Rasulullah, yang ada justru hadis-hadis tersebut menguatkan satu sama lain". ${ }^{58}$

\section{SIMPULAN}

Dari pembahasan ini penulis menyimpulkan: pertama, Jalaludin Rakhmat tidak mendiskripsikan tentang konsep hadis mudhtharib secara jelas. Upaya yang ia lakukan dalam melihat hadis-hadis Shahih alBukhari yang ia anggap mudhtharib adalah dengan cara melihat beberapa kontradiksi

\footnotetext{
${ }^{56}$ Ad-Dimasyqî, v, p. 256.

${ }^{57}$ Al-‘Aini, XII, p. 279.

58 Ibnu Qayyim Al-Jauziyyah, Zâd Al-Ma'âd Fî
} Hady Khair Al-'Ibâd, ed. by Syu'aib al-Arnaûth \& 'Abd al-Qâdir Al-Arnaûth (Beirut: Muassasah arRisâlah, 2000), III, p. 596. 
lafzhiyyah yang timbul dari hadis yang dimaksud.

Kedua, argumentasi Jalal dalam menentukan kemudhthariban hadis adalah dengan cara melihat beberapa kontradiksi matan secara lafzhiyyah. Indikasi-indikasi mudhtharib yang ia suguhkan hanya berdasarkan kepada perbedaan lafazh yang terjadi di antara beberapa riwayat hadis yang ia maksud, itupun hanya dilakukan berdasarkan asumsi sederhana, bukan berdasarkan analisis yang matang.

Ketiga, terdapat kelemahan metodologis yang dilakukan oleh Jalal dalam buku AlMushthafa dengan beberapa alasan: 1) Studi kritis yang dilakukan oleh Jalal berbeda dengan kebanyakan yang biasa dipakai oleh para ahli hadis, khususnya mengenai hadis mudhtharib. Konsep mudhtharib yang disebutkan oleh Jalal tidak jelas dan jauh berbeda dengan konsep yang sudah dirumuskan dan disepakati oleh mayoritas ulama hadis. 2) Asumsi Jalal yang mengatakan bahwa hadis-hadis tentang Abu Bakar menjadi imam salat yang terdapat dalam Shahih al-Bukhari itu dianggap sebagai hadis mudhtharib, tidak terbukti kebenarannya. Beberapa indikasi mudhtharib yang ia suguhkan untuk memperkuat statemennya tidak lebih memperkuat asumsinya karena pada kenyataannya hadishadis yang dimaksud oleh Jalal tidak terbukti sebagai hadis mudhtharib. Hadis-hadis yang disebutkan oleh Jalal sebagai hadis mudhtharib itu memiliki derajat yang sama kuatnya, masing-masing hadis juga menceritakan kondisi dan peristiwa yang terjadi pada waktu dan tempat yang berlainan. Maka perbedaan lafazh dan makna yang terjadi di antara hadis-hadis tersebut sangat wajar jika dipahami secara berbeda pula. Artinya, bahwa hadis-hadis tersebut bisa diterima keabsahannya dan bisa dijadikan hujjah, karena perbedaan lafazh hadis itu tidak serta merta menjadikan suatu hadis dianggap idhthirâb atau ikhtilaf.

\section{DAFTAR PUSTAKA}

Ad-Dimasyqî, 'Imâd ad-Dîn Abû al-Fidâ bin Katsîr, Al-Bidâyah Wa an-Nihâyah, ed. by 'Alî Syairî (Beirut: Dâr Ihyâ at-Turâts al-
'Arabî, 1988), V

Al-'Aini, Badruddin, Umdah Al-Qari Syarh Shahih Al-Bukhar (Beirut: Dar Kutub al'Ilmiyyah, 2001), XII

Al-'Asqalânî, Abu al-Fadl Ahmad bin 'Ali bin Hajr, Fath Al-Bârî, ed. by Abu Qutaibah Nadhr Muhammad Al-Faryabi (Dar Thayibah), II

Al-'Asqalânî, Abu al-Fadl Ahmad bin 'Ali bin Hajr, Hadyu as-Sârî Muqaddimah Fath AlBârî (Riyadh: Dâr as-Salâm, 2000)

Al-Andalusî, Abû 'Ubaid 'Abd Allâh, Mu'jam Mâ Ista'jam Min Asmâ' Al-Bilâd Wa AlMawâdhi' (Beirut: 'âlam al-Kutub, 1982), III

Al-Azhari, Zainuddin bin Ahmad al-Anshari, Syarh Alfiyah Al-'Iraqi, ed. by Muhammad al-'Iraqi Al-Husaini (Beirut: Dar al-Kutub al-'Ilmiyyah)

Al-Harabî, 'Âtiq bin Ghaits, Mu'jam Al-Ma'âlim Al-Jugrâfiyyaah $F i$ as-Sîroh anNabawiyyah (makah al mukarommah: Dâr Makkah, 1982)

Al-Haran, Taqiyuddîn Abû al-'Abbâs Ahmad bin 'Abdulhalîm bin Taimiyyah, Majmû' AlFatawâ, ed. by 'Abdurrahmân bin Muhammad bin Qâsim (Madinah: Majma' al-Malik Fahd li Thaba'ah al-Mushahaf asySyarîf, 1995), XX

Al-Humairî, Abû 'Abdullah Muhammad, $A r$ Raudh Al-Mu'thar Fî̀ Khabar Al-'Aqthâr, ed. by Ihsân 'Abbâs (Beirut: Muassasah Nâshir li ats-Tsaqâfah, 1980)

Al-Humairî, Abû ar-Rabî' Sulaimân bin Mûsâ, Al-Iktifâ Bimâ Tadhammanah Min Maghâzî Rasulillâh Wa Ats-Tsalâsah Al-Khulafâ (Beirut: Dâr al-Kutub al-'Ilmiyyah, 1999), II

Al-Jauziyyah, Ibnu Qayyim, Zâd Al-Ma'âd Fî Hady Khair Al-'Ibâd, ed. by Syu'aib alArnaûth \& 'Abd al-Qâdir Al-Arnaûth (Beirut: Muassasah ar-Risâlah, 2000), III

Al-Kandahlawî, Muhammad Yûsuf bin Muhammad Ismâ'̂̂l, Hayâh Ash-Shahâbah, ed. by Basyâr 'Awwâd Ma'rûf (Beirut: Muassasah ar-Risâlah, 1999), II

Al-Muâfirî, Abû Muhammad 'Abd al-Malik bin Hisyâm, As-Sîrah an-Nabawiyyah Li Ibnu Hisyâm, ed. by Mushthafâ As-Saqâ (kairo: Syirkah Maktabah Mushthafâ al-Bâbi alHalabî, 1995), II

Al-suyuti, abd al-Rahman bin abi bakar jalaludin, Tadrib Al Rawiy Fi Syarhi Taqrib Al Nawawi (maktabah syamilah)

Al-Waluwwi, Muhammad bin al-'Allamah, Syarh Alfiyah as-Suyûthî Fî Al-Hadîs (Madinah: Maktabah al-Ghurabâ al- 
Atsariyyah, 1993), I

An-Najdî, Muhammad bin 'Abd al-Wahhab, Mukhtashar Sîrah Ar-Rasûl Shallallahu 'alaihi Wa Sallam (Riyadh: Wizârah asySyư ûn al-Isliyyah wa al-Auqâf wa adDa'wah wa al-Irsyâd, 1997)

As-Sakhâwî, Syamsuddîn Abû al-Khair Muhammad bin 'Abdurrahmân, Fath AlMughîts Bisyarh Alfiyyah Al-Hadîs, ed. by 'Abdulkarîm bin 'Abdirrahmân AlKhudhair (Riyadh: Maktabah Dâr alMinhâj, 2005), I

Asy-Syahrazuri, Abu 'Amr 'Abdurrahman, Muqaddimah Ibnu Shalah Fî 'Ulum AlHadis (kairo: Dar al-Hadis, 2010)

Asy-Syaibânî, 'Izzuddîn Abû Hasan 'Alî bin Abî al-Kiram bin Atsîr, Al-Kâmil Fî at-Târîkh, ed. by Abû al-Fidâ 'Abdullâh Al-Qâdhî (Beirut: Dâr al-Kutub al-'Ilmiyyah, 1987), II Asy-Syâmî, Muhammad bin Yûsuf ash-Shâlhî, Subul Al-Hady Wa Ar-Rasyâd Fî̀ Sirrah Khair Al-'Ibâd, ed. by Syaikh 'Âdil Ahmad 'Abd Al-Maujûd (Beirut: Dar al-Kutub al'Ilmiyyah, 1993), XII

Asy-Syaukani, Muhammad bin 'Ali bin Muhammad bin 'Abdillah, Irsyad Al-Fuhul Ila Tahqiq Al-Haqq Min 'Ilm Al-Ushul, ed. by Asy-Syaikh Ahmad 'Auz 'Inayah (Beirut: Dâr al-Kutub al-'Arâbî, 1999), I - Oathr Al-Wali 'ala Hadis Al-Wali (kairo: Dâr al-Kutub al-Hadîtsah)
Atabik 'Ali, Kamus al-'Ashri, Kamus Al-'Ashri (Yogyakarta: Yayasan Ali Maksum Ma'had Krapyak, 1996)

Ath-Thabari, Abu Ja'far Jarir, Târîkh AthThabarî, ed. by Shidqi Jamîl Al-'Athâr (Beirut: Dâr al-Fikr, 1998), III

Bakrî, Husain bin Muhammad al-Hasan adDiyâr, Târîkh Al-Khamîs Fî̀ Ahwâl Anfus an-Nafìs (Beirut: Dâr Shâdir), II

Ibn Rajab al-Hanbali, Fath Al-Bari Syarh Shahih Al-Bukhari (Madinah: Maktabah alGhuraba al-Asariyyah, 1996), III

Ma'luf, Lois, Al-Munjid (Beirut: Al-Maktabah alsyarkiah, 1986)

Rakhmat, Jalaludin, Al-Mushthafa (Bandung: Muthahhari Press, 2002)

Shalâhuddîn Abû Sa'îd Khalîl bin Kîkaldî al'Alâ'î, Tahqî̀q Al-Murâd Fî Anna an-Nahy Yaqtadhî Al-Fasâd (Kuwait: Dâr al-Kutub ats-Tsaafiyyah)

Syâkir, Ahmad Muhammad, Al-Bâ'its Al-Hatsîts; Syarh Ikhtishâr 'Ulûm Al-Hadîs Li AlHâfizh Ibnu Katsîr (Riyadh: Maktabah Dâr as-Salâm, 1994)

Syurrâb, Muhammad bin Muhammad Hasan, AlMa'âlim Al-Atsîrah Fî as-Sunnah Wa asSirâh (Beirut: Dâr al-Qalam, 1990) 